\title{
PENGARUH PERBANDINGAN TEPUNG BERAS (Oryza sativa) DAN LABU KUNING (Cucurbita moschata Durch) TERHADAP KARAKTERISTIK SUMPING LABU
}

\section{THE EFFECT OF RICE FLOUR (Oryza sativa) AND PUMKIN (Cucurbita moschata Durch) RATIO ON THE CHARACTERISTICS OF PUMPKIN SUMPING}

\author{
Aini Amalia ${ }^{1)}$,A.A.G.N. Anom Jambe ${ }^{2)}$, Ni Luh Ari Yusasrini ${ }^{2)}$ \\ ${ }^{1}$ Mahasiswa Program Studi Ilmu dan Teknologi Pangan, Fakultas Teknologi Pertanian, Unud \\ ${ }^{2}$ Dosen Program Studi Ilmu dan Teknologi Pangan, Fakultas Teknologi Pertanian, Unud \\ Kampus Bukit Jimbaran, Badung-Bali
}

\begin{abstract}
The purposes of this research were to know the effect of rice flour and pumpkin ratio on the characteristics of sumping and to find the right ratio from rice flour and pumpkin to produce sumping with the best characteristics. The completely randomized design was used in the research with treatment that is the ratio rice flour with pumpkin which consist of $25 \%: 75 \% ; 30 \%: 70 \% ; 35 \%$ : 65\%; 40\%: 60\%; 45\%:55\%; 50\%:50\%. The treatment was repeated 3 times to obtained 18 units. The data obtained were analyzed of variance and if the treatment had an effect on the variable then continued with Duncan test. The results showed that rice flour and pumpkin ratio had significant effect to water content, ash content, total caroten, skoring test (colour, aroma, texture, taste) and hedonic test (colour, aroma, texture, taste, and overall acceptance). The ratio of rice flour $25 \%$ and pumpkin $75 \%$ produces with the best characteristic namely water content $57,55 \%$, ash content $1,74 \%$, total caroten content $10868,52 \mu \mathrm{g} / \mathrm{g}$, color yellow and like, flavor pumkin typical and rather like, texture chewy and like, taste typical pumkin and like and overall acceptance like.
\end{abstract}

Keywords : Rice flour, pumpkin, pumpkin sumping

\section{PENDAHULUAN}

Sumping labu atau waluh adalah jajanan tradisional Bali dan di Indonesia dikenal dengan nama kue nagasari (Anon, 2012). Sumping terbuat dari tepung beras, kelapa parut, gula, garam dan air yang kemudian dibungkus dengan daun pisang dan di kukus. Biasanya pada masyarakat Indonesia khususnya masyarakat Bali sumping digunakan untuk acara keagamaan tetapi sekarang sumping sudah dijadikan makanan sehari-hari oleh masyarakat. Sumping biasanya berisikan irisan buah pisang, nangka dan lainnya untuk menambah citarasa. Pada pembuatan sumping labu ada penambahan labu kuning, pemberian labu kuning pada sumping memiliki kelebihan yaitu meningkatkan kandungan gizi dan memberi warna yang lebih menarik pada produk.

Labu kuning merupakan bahan pangan yang memiliki kandungan zat gizi yang cukup lengkap antara lain mengandung vitamin B, C dan beberapa jenis mineral. Disamping itu labu kuning mengandung beta karoten atau provitamin A (pigmen berwarna orange) sehingga dapat digunakan sebagai pewarna alami dalam pembuatan produk pangan (Hendrasty, 2003). Labu kuning dianggap sebagai sumber $\beta$-karoten dengan keunggulan antara lain dapat meningkatkan sistem 
imunitas serta mencegah penyakit jantung dan kanker.

Dipasaran sumping labu banyak ditemui dan digemari masyarakat. Sumping labu memiliki warna yang menarik dan rasa yang khas. Dari hasil survei pasar menunjukan adanya perbedaan tekstur sumping labu dari setiap pembuat dari bertekstur lembek sampai keras. Hal ini disebabkan karena perbandingan tepung beras dan labu kuning yang berbedabeda sehingga diperoleh karakteristik sumping labu yang beragam. Penggunaan jumlah tepung beras dan labu kuning yang tidak tepat mempengaruhi karakteristik sumping labu yang dihasilkan (Anon, 2016). Saat ini belum ada formulasi yang pasti khususnya perbandingan antara tepung beras dan labu kuning dalam pembuatan sumping labu oleh karena itu dilakukan penelitian untuk mengetahui formulasi sumping labu agar diperoleh karakteristik sumping labu yang terbaik.

\section{METODE PENELITIAN}

\section{Tempat dan Waktu}

Penelitian ini akan dilakukan di Laboratorium Pengolahan Pangan, Laboratorium Analisis Pangan, Laboratorium Rekayasa Proses dan Pengendalian Mutu Fakultas Teknologi Pertanian, Universitas Udayana. Penelitian ini dilaksanakan dari bulan April sampai Mei 2018

\section{Bahan dan Alat}

Bahan-bahan yang digunakan dalam melaksanakan penelitian ini adalah labu kuning,tepung beras (rose brand), daun pisang, gula, garam dan kelapa parut yang didapatkan dari Pasar Soputan Jalan Gn. Soputan, Pemecutan Klod Denpasar. Bahan kimia yang digunakan dalam melakukan analisis meliputi alkohol, aquades, $\beta$-karoten murni, kloroform, petroleum benzena, aseton dan $\mathrm{Na}_{2} \mathrm{SO}_{4}$.

Alat-alat yang digunakan dalam pengolahan terdiri dari talenan, pisau, baskom, panci pengukus, kompor gas, sendok. Sedangkan alat analisis kimia yang digunakan yaitu oven (Cole Palmer-Stable), muffle, timbangan analitik (Methler Toledo AB-204), kertas saring Whatman, botol timbang, pipet tetes, pipet volume, spektrofotometer (Unico UV 2100), cawan porselin, tabung reaksi, batang pengaduk, desikator, corong, labu takar (Pyrex), gelas ukur (Pyrex), gelas beker, vortex, penjepit, alumunium foil, waterbath, soxlet, erlenmeyer dan lumpang.

\section{Rancangan Percobaan}

Rancangan yang digunakan pada penelitian ini adalah Rancangan Acak Lengkap (RAL) dengan perlakuan perbandingan labu kuning dengan tepung beras sebagai berikut :

$\mathrm{P} 1=75 \%$ labu kuning $\quad: \quad 25 \%$ tepung beras P2 $=70 \%$ labu kuning $: 30 \%$ tepung beras $\mathrm{P} 3=65 \%$ labu kuning : $35 \%$ tepung beras $\mathrm{P} 4=60 \%$ labu kuning : $40 \%$ tepung beras P5 $=55 \%$ labu kuning : $45 \%$ tepung beras P6 $=50 \%$ labu kuning : $50 \%$ tepung beras

Masing-masing perlakuan diulang sebanyak tiga kali sehingga diperoleh 18 unit percobaan. Data yang diperoleh dari hasil penelitian dianalisis dengan sidik ragam 
(ANOVA) melalui program SPSS 21 dan apabila perlakuan berpengaruh terhadap variabel maka dilanjutkan dengan uji Duncan's Multiple Range Test (DMRT) (Gomez dan Gomez, 1995).

\section{Pelaksanaan Penelitian}

Proses pelaksanaan penelitian terdiri dari dua tahapan, diantaranya : Tahap pertama proses pembuatan labu kuning parut yaitu labu kuning dipotong kemudian dihilangkan kulit dan bijinya dan dicuci untuk menghilangkan kotoran, setelah itu labu kuning diparut. Diagram alir proses pemarutan labu kuning dapat dilihat pada Gambar 1.

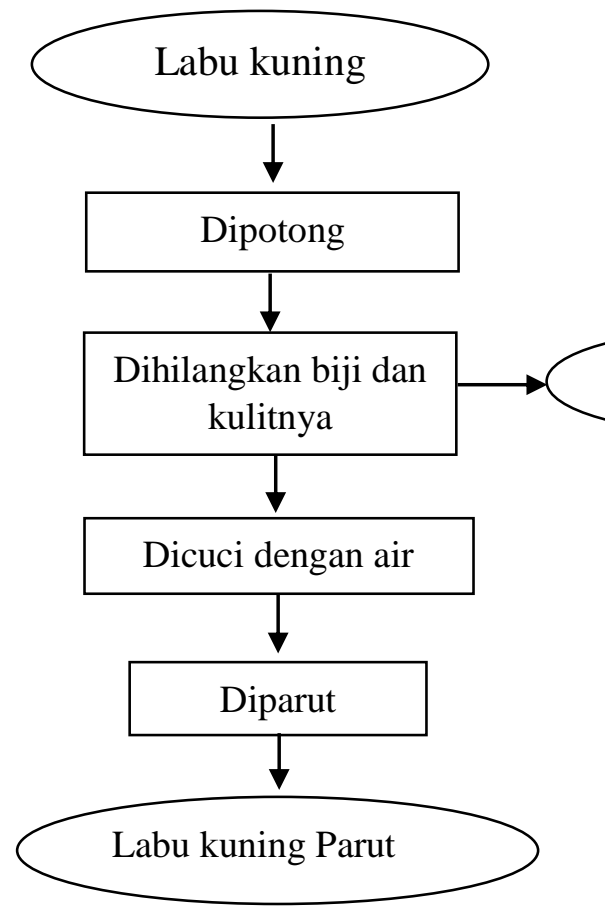

Gambar 2. Diagram Alir Proses Pembuatan

Labu Kuning Parut (Anon, 2016)

Tahap kedua yaitu proses pembuatan sumping labu sebagai berikut : tepung beras (rose brand) sesuai perlakuan dimasukkan kedalam wadah ditambahkan air panas $20 \mathrm{ml}$ lalu diuleni kemudian ditambahkan parutan labu kuning seseuai perlakuan, kelapa parut 5 $\mathrm{g}$, gula $20 \mathrm{~g}$ dan garam $2 \mathrm{~g}$ yang sudah disesuaikan takarannnya seperti pada Gambar.

2. Bahan-bahan tersebut dicampur dengan cara diuleni selama 5 menit sampai bahan tersebut menjadi adonan dan menyatu lalu dibungkus dengan daun pisang sebanyak $25 \mathrm{~g}$ dan dikukus selama 1 jam. Adapun diagram alir proses pembuatan sumping labu dapat dilihat pada Gambar 2. Formulasi pembuatan sumping labu dapat dilihat pada Tabel 1.

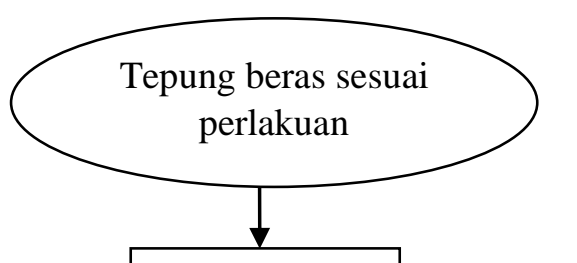

Ditimbang

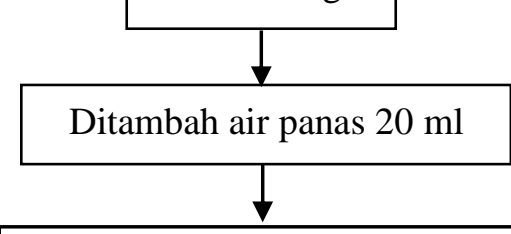

Ditambah labu kuning parut sesuai perlakuan

\section{Kulit dan biji}
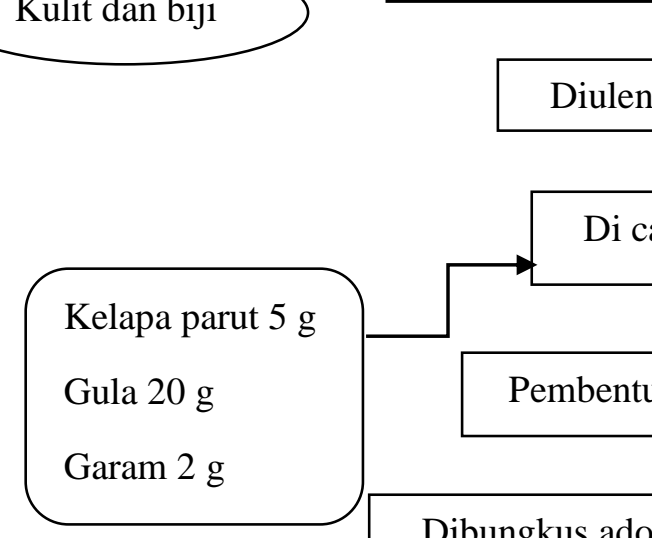

Diuleni 5 menit

Di campur

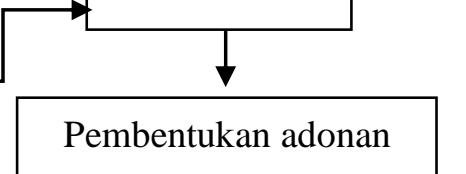

Dibungkus adonan sebanyak $25 \mathrm{~g}$

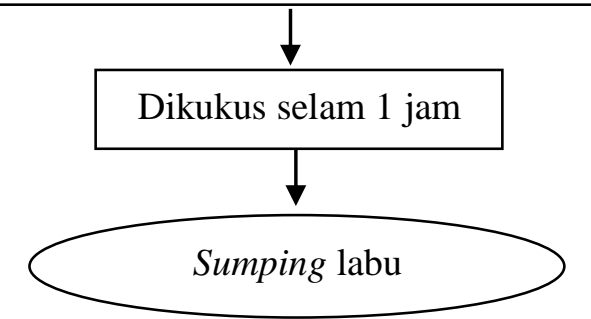

Gambar 2. Diagram Alir Proses Pembuatan

Sumping Labu (Anon, 2016) 
Tabel 1. Formulasi pembuatan sumping labu (Anon, 2016)

\begin{tabular}{|c|c|c|c|c|c|c|c|}
\hline \multirow{2}{*}{ No } & \multicolumn{7}{|c|}{ Perlakuan } \\
\hline & Komposisi & $\mathrm{P} 1$ & $\mathrm{P} 2$ & $\mathrm{P} 3$ & $\mathrm{P} 4$ & P5 & P6 \\
\hline 1. & Labu kuning (g) & 75 & 70 & 65 & 60 & 55 & 50 \\
\hline 2. & Tepung beras $(\mathrm{g})$ & 25 & 30 & 35 & 40 & 45 & 50 \\
\hline 3. & Gula (g) & 20 & 20 & 20 & 20 & 20 & 20 \\
\hline 4. & Air panas (ml) & 20 & 20 & 20 & 20 & 20 & 20 \\
\hline 5. & Garam $(g)$ & 2 & 2 & 2 & 2 & 2 & 2 \\
\hline 6 & Kelapa parut (g) & 5 & 5 & 5 & 5 & 5 & 5 \\
\hline
\end{tabular}

Keterangan : Persentase berdasarkan jumlah tepung beras dan labu kuning (100 g)

\section{Variabel yang Diamati}

Variabel yang diamati dalam penelitian ini adalah kadar air dengan metode pengeringan (Sudarmadji et al., 1997), kadar abu dengan metode pengabuan (Sudarmadji et

\section{HASIL DAN PEMBAHASAN}

Hasil analisis kadar air, kadar abu, kadar total karotenoid dari tepung beras dan al., 1997), total karotenoid dengan metode spektrofotometri (Muchtadi, 1989) dan sifat sensoris menggunakan uji hedonik terhadap tekstur, aroma, rasa, warna dan penerimaan keseluruhan serta uji skoring terhadap tekstur, aroma, rasa, warna (Soekarto, 1985).

labu kuning yang digunakan dapat dilihat pada Tabel 2 .

Tabel 2. Nilai rata-rata hasil analisis kadar air, kadar abu dan total karotenoid dari tepung beras dan labu kuning.

\begin{tabular}{lcc}
\hline \multicolumn{1}{c}{ Komponen } & Tepung Beras & Labu Kuning \\
\hline Air $(\%)$ & 12,36 & 89,51 \\
Abu $(\%)$ & 0,37 & 0,54 \\
Total karotenoid $(\mu \mathrm{g} / \mathrm{g})$ & 0 & 11804,48 \\
\hline
\end{tabular}

Hasil analasis menunjukkan bahwa labu kuning yang menjadi bahan baku dari penelitian ini mengandung kadar air $89,51 \%$, kadar abu $0,54 \%$ dan total karotenoid $11804,48 \mu \mathrm{g} / \mathrm{g}$, sedangkan tepung beras yang menjadi bahan baku mengandung kadar air
$12,36 \%$, kadar abu $0,37 \%$ dan total karotenoid $0(\mu \mathrm{g} / \mathrm{g})$.

Hasil analisis kadar air, kadar abu, total karotenoid dari sumping labu dapat dilihat pada Tabel 3. 
Tabel 3. Rata-rata kadar air, kadar abu, total karotenoid dari sumping labu

\begin{tabular}{|c|c|c|c|}
\hline $\begin{array}{c}\text { Perlakuan Tepung beras dan Labu } \\
\text { Kuning }\end{array}$ & $\begin{array}{l}\text { Kadar } \\
\text { Air }(\%)\end{array}$ & Kadar Abu (\%) & $\begin{array}{l}\text { Total Karotenoid } \\
\qquad(\mu \mathrm{g} / \mathrm{g})\end{array}$ \\
\hline P1 (25\%: 75\%) & $57,55 \pm 0,22 \mathrm{a}$ & $1,74 \pm 0,18 \mathrm{a}$ & $10868,52 \pm 105,24 a$ \\
\hline P2 (30\%: $70 \%)$ & $54,63 \pm 0,90 \mathrm{~b}$ & $1,70 \pm 0,19 b$ & $9748,65 \pm 185,51 b$ \\
\hline P3 (35\%: 65\%) & $51,09 \pm 0,59 \mathrm{c}$ & $1,67 \pm 0,14 \mathrm{c}$ & $8606,89 \pm 266,33 \mathrm{c}$ \\
\hline P4 (40\%: 60\%) & $50,49 \pm 2,41 \mathrm{~d}$ & $1,57 \pm 0,14 \mathrm{~d}$ & $7593,58 \pm 380,37 \mathrm{~d}$ \\
\hline P5 (45\%: $55 \%)$ & $49,66 \pm 0,90 \mathrm{~cd}$ & $1,28 \pm 0,14 \mathrm{e}$ & $6743,21 \pm 143,70 \mathrm{e}$ \\
\hline P6 (50\%: $50 \%)$ & $48,05 \pm 1,57 \mathrm{~d}$ & $1,16 \pm 0,11 \mathrm{e}$ & $5697,98 \pm 374,23 \mathrm{f}$ \\
\hline
\end{tabular}

Keterangan : Nilai rata - rata yang diikuti oleh huruf yang berbeda pada kolom yang sama menunjukkan berbeda nyata pada Uji Duncan 0,05.

\section{Kadar Air}

Hasil analisis ragam menunjukkan bahwa perbandingan tepung beras dengan labu kuning berpengaruh sangat nyata $(\mathrm{P}<0,01)$ terhadap kadar air sumping labu. Tabel 3 menunjukkan kadar air tertinggi sumping labu diperoleh dari perlakuan 25\% tepung beras dengan $75 \%$ labu kuning (P1) yaitu 57,55\% sedangkan kadar air terendah sumping labu diperoleh dari perlakuan $50 \%$ tepung beras dengan 50\% labu kuning (P6) yaitu 48,05\%. Semakin banyak konsentrasi penambahan labu kuning menyebabkan kadar air sumping labu meningkat, hal ini dikarenakan oleh tingginya kandungan kadar air labu kuning segar lebih tinggi dibandingkan kadar air tepung beras. Berdasarkan hasil analisis bahan baku kandungan kadar air labu kuning lebih tinggi yaitu sebesar $89,51 \%$ dibandingkan dengan tepung beras yaitu sebesar 12,36\% (Tabel 2).

\section{Kadar Abu}

Hasil analisis ragam menunjukkan bahwa perbandingan tepung beras dengan labu kuning berpengaruh sangat nyata $(\mathrm{P}<0,01)$ terhadap kadar abu sumping labu. Tabel 3 menunjukkan kadar abu sumping labu tertinggi diperoleh dari perlakuan P1 yaitu 1,74\%, sedangkan kadar abu terendah sumping labu diperoleh dari perlakuan P6 yaitu 1,16\%. Penentuan kadar abu bertujuan untuk mengetahui banyaknya kandungan mineral yang terdapat dalam sumping labu.

Kadar abu sumping labu bertambah seiring dengan tingginya penambahan labu kuning. Hal ini dikarenakan labu kuning mengandung mineral lebih tinggi dibandingkan dengan tepung beras sehingga semakin banyak penambahan labu kuning kadar abu sumping labu tinggi. Berdasarkan hasil analisis bahan baku kadar abu labu kuning yaitu $0,54 \%$ lebih besar dari pada kadar abu tepung beras yaitu $0,37 \%$ (Tabel 2). Kandungan mineral dalam labu kuning adalah kalsium $(45,00 \mathrm{mg} / 100 \mathrm{~g})$, fosfor $(64,00 \mathrm{mg} / 100 \mathrm{~g})$ dan besi $(1,40$ $\mathrm{mg} / 100 \mathrm{~g}$ ) (Hendrasty, 2003). Mineral berfungsi sebagai zat pembangun dan pengatur di dalam tubuh. Beberapa fungsi mineral dalam tubuh diantaranya kalsium berperan dalam membentuk tulang dan gigi serta mengatur proses biologis, fosfor berperan dalam penyimpanan dan pengeluaran energi 


\section{Total Karoten}

Hasil analisis ragam menunjukkan bahwa perbandingan tepung beras dengan labu kuning berpengaruh sangat nyata $(\mathrm{P}<0,01)$ terhadap total karotenoid sumping labu. Tabel 3 menunjukkan total karotenoid tertinggi sumping labu diperoleh dari perlakuan P1 yaitu 10868,52 $\mu \mathrm{g} / \mathrm{g}$ sedangkan total karotenoid terendah sumping labu diperoleh dari perlakuan P6 yaitu 5697,98 $\mu \mathrm{g} / \mathrm{g}$.

\section{Evaluasi Sifat Sensoris}

Hasil analisis ragam nilai rata-rata penilaian uji hedonik sumping labu dapat dilihat pada Tabel 4. Nilai rata-rata uji skoring
Total karotenoid sumping labu bertambah seiring dengan tingginya konsentrasi penambahan labu kuning. Berdasarkan hasil analisis bahan baku total karotenoid labu kuning yaitu $11804,48 \mu \mathrm{g} / \mathrm{g}$ lebih besar dari pada total karotenoid tepung beras yaitu $0 \mu \mathrm{g} / \mathrm{g}$ (Tabel 2). Beta karoten merupakan sumber terbaik dari salah satu vitamin penting yakni vitamin A yang diperlukan untuk meningkatkan kesehatan mata dan kulit.

terhadap warna, aroma, tekstur, dan rasa dapat dilihat pada pada Tabel 5 .

Tabel 4. Nilai rata-rata uji hedonik warna, aroma, tekstur, rasa dan penerimaan keseluruhan sumping labu

\begin{tabular}{|c|c|c|c|c|c|}
\hline \multirow{2}{*}{$\begin{array}{c}\text { Perlakuan } \\
\text { Tepung Beras } \\
\text { Dengan Labu } \\
\text { Kuning }\end{array}$} & \multicolumn{5}{|c|}{ Nilai Rata-Rata Uji Hedonik } \\
\hline & Warna & Aroma & Tekstur & Rasa & $\begin{array}{l}\text { Penerimaan } \\
\text { Keseluruhan }\end{array}$ \\
\hline $25 \%: 75 \%(\mathrm{P} 1)$ & $5,60 \mathrm{a}$ & $6,00 \mathrm{a}$ & $5,67 \mathrm{a}$ & $5,93 \mathrm{a}$ & $6,20 \mathrm{a}$ \\
\hline $30 \%: 70 \%(\mathrm{P} 2)$ & $5,47 \mathrm{a}$ & $5,73 \mathrm{ab}$ & $5,33 \mathrm{a}$ & $5,47 \mathrm{ab}$ & $5,93 \mathrm{a}$ \\
\hline $35 \%: 65 \%(\mathrm{P} 3)$ & $4,93 \mathrm{ab}$ & $5,33 \mathrm{ab}$ & $4,87 \mathrm{a}$ & $4,87 \mathrm{bc}$ & $5,13 \mathrm{~b}$ \\
\hline $40 \%: 60 \%(\mathrm{P} 4)$ & $4,87 \mathrm{ab}$ & $5,00 \mathrm{bc}$ & $3,93 \mathrm{~b}$ & $4,27 \mathrm{~cd}$ & $4,60 \mathrm{bc}$ \\
\hline $45 \%: 55 \%(\mathrm{P} 5)$ & $4,67 \mathrm{ab}$ & $4,33 \mathrm{~cd}$ & $3,67 \mathrm{~b}$ & $3,80 \mathrm{de}$ & $4,13 \mathrm{c}$ \\
\hline $50 \%: 50 \%(\mathrm{P} 6)$ & $4,07 \mathrm{~b}$ & $3,53 \mathrm{~d}$ & $3,13 \mathrm{~b}$ & $3,50 \mathrm{e}$ & $3,53 \mathrm{~d}$ \\
\hline
\end{tabular}

Keterangan : Nilai rata - rata yang diikuti oleh huruf yang berbeda pada kolom yang sama menunjukkan berbeda nyata pada Uji Duncan 0,05.

\section{Warna}

Hasil analisis ragam menunjukkan bahwa perbandingan tepung beras dengan labu kuning berpengaruh sangat nyata $(\mathrm{P}<0,01)$ terhadap kesukaan warna sumping labu. Tabel 4 menunjukkan bahwa nilai tertinggi tingkat kesukaan panelis terhadap warna sumping labu diperoleh dari perlakuan P1 yaitu 5,60 (suka) serta tidak berbeda dengan perlakuan P2, P3 dan P4 sedangkan nilai kesukaaan terendah terhadap warna diperoleh dari perlakuan P6 yaitu 4,07 (biasa). Perbandingan tepung beras dengan labu kuning berpengaruh sangat nyata $(\mathrm{P}<0,01)$ terhadap skor warna sumping labu. 
Tabel 5 menunjukkan bahwa nilai rata-rata penerimaan terhadap warna uji skoring sumping labu tertinggi diperoleh dari perlakuan P1 yaitu 4,67 (kuning tua) dan terendah diperoleh dari perlakuan P6 yaitu 2,27 (putih kekuningan).

Panelis menyukai sumping labu dengan perlakuan P1 yang berwarna kuning hal ini disebabkan warna pada labu kuning sehingga mempengaruhi warna produk akhir makanan (See, et al.,2007). Menurut Winarno (2004) warna merupakan komponen yang penting untuk menentukan kualitas atau derajat penerimaan suatu bahan pangan. Suatu bahan pangan meskipun dinilai enak dan teksturnya sangat baik, tetapi memiliki warna yang tidak menarik atau memberi kesan telah menyimpang dari warna yang seharusnya maka bahan tersebut tidak akan dikonsumsi. Penentuan mutu suatu bahan pangan pada umumnya tergantung pada warna karena warna tampil terlebih dahulu.

Tabel 5. Nilai rata-rata uji skoring warna, aroma, tekstur dan rasa sumping labu

\begin{tabular}{|c|c|c|c|c|}
\hline \multirow{2}{*}{$\begin{array}{c}\text { Perlakuan } \\
\text { Tepung Beras Dengan Labu } \\
\text { Kuning }\end{array}$} & \multicolumn{4}{|c|}{ Nilai Rata - Rata Uji Skoring } \\
\hline & Warna & Aroma & Tekstur & Rasa \\
\hline $25 \%: 75 \%(\mathrm{P} 1)$ & $4,67 \mathrm{a}$ & $4,53 \mathrm{a}$ & $4,53 \mathrm{a}$ & $4,53 \mathrm{a}$ \\
\hline $30 \%: 70 \%(\mathrm{P} 2)$ & $4,00 \mathrm{~b}$ & $3,93 \mathrm{~b}$ & $3,93 \mathrm{~b}$ & $4,00 \mathrm{a}$ \\
\hline $35 \%: 65 \%(\mathrm{P} 3)$ & $3,60 \mathrm{~b}$ & $3,33 \mathrm{c}$ & $3,60 \mathrm{~b}$ & $3,13 \mathrm{~b}$ \\
\hline $40 \%: 60 \%(\mathrm{P} 4)$ & $3,07 \mathrm{c}$ & $2,87 \mathrm{~d}$ & $2,53 \mathrm{c}$ & $2,80 \mathrm{bc}$ \\
\hline $45 \%: 55 \%(\mathrm{P} 5)$ & $2,87 \mathrm{c}$ & $2,80 \mathrm{~cd}$ & $1,93 \mathrm{~d}$ & $2,53 \mathrm{~cd}$ \\
\hline $50 \%: 50 \%(\mathrm{P} 6)$ & $2,27 \mathrm{~d}$ & $2,27 \mathrm{~d}$ & $1,27 \mathrm{e}$ & $2,07 \mathrm{~d}$ \\
\hline
\end{tabular}

Keterangan : Nilai rata - rata yang diikuti oleh huruf yang berbeda pada kolom yang sama menunjukkan berbeda nyata pada Uji Duncan 0,05.

\section{Aroma}

Hasil analisis ragam menunjukkan bahwa perbandingan tepung beras dengan labu kuning berpengaruh sangat nyata $(\mathrm{P}<0,01)$ terhadap aroma sumping labu. Tabel 4 menunjukkan bahwa nilai tertinggi tingkat kesukaan panelis terhadap aroma sumping labu diperoleh dari perlakuan P1 yaitu 6,00 (suka) serta tidak berbeda dengan perlakuan P2 dan P3 sedangkan nilai kesukaaan terendah terhadap aroma diperoleh dari perlakuan P6 yaitu 3,53 (agak tidak suka) serta tidak berbeda dengan P5. Perbandingan tepung beras dengan labu berpengaruh sangat nyata $(\mathrm{P}<0,01)$ terhadap skor aroma sumping labu. Tabel 5 menunjukkan bahwa nilai rata-rata penerimaan terhadap aroma uji skoring sumping labu tertinggi diperoleh dari perlakuan P1 yaitu 4,53 (khas labu kuning), dan terendah diperoleh dari perlakuan P6 yaitu 2,27 (tidak beraroma labu kuning) tidak berbeda dengan perlakuan P4 dan P5.

Panelis menyukai sumping labu dengan perlakuan P1 yang beraroma khas labu 
kuning. Hal ini disebabkan karena semakin tinggi konsentrasi labu kuning sehingga aroma labu kuning pada sumping labu semakin kuat.

\section{Tekstur}

Hasil analisis ragam menunjukkan bahwa perbandingan tepung beras dengan labu kuning berpengaruh sangat nyata $(\mathrm{P}<0,01)$ terhadap tekstur sumping labu. Tabel 4 menunjukkan nilai rata-rata tingkat kesukaan panelis terhadap nilai kesukaan tekstur sumping labu berkisar 5,67 (suka) sampai dengan 3,13 (agak suka). Perbandingan tepung beras dengan labu kuning berpengaruh sangat nyata $(\mathrm{P}<0,01)$ terhadap skor tekstur sumping labu. Tabel 5 menunjukkan bahwa nilai penerimaan terhadap tekstur uji skoring sumping labu tertinggi diperoleh dari perlakuan P1 yaitu 4,53 (kenyal) sedangkan nilai terendah diperoleh dari perlakuan P6 yaitu 1,27 (agak keras) .

Semakin banyak penambahan labu kuning menyebabkan tekstur sumping labu semakin lembek karena labu kuning memiliki kandungan air yang tinggi. Keberadaan air dalam suatu produk akan mempengaruhi tekstur karena air yang di dalamnya akan mempengaruhi keras dan lunaknya produk (Apriliyani, 2010). Panelis menyukai sumping labu dengan perlakuan P2 yang bertekstur kenyal

\section{Rasa}

Hasil analisis ragam menunjukkan bahwa perbandingan tepung beras degan labu kuning berpengaruh sangat nyata $(\mathrm{P}<0,01)$ terhadap rasa sumping labu. Tabel 4 menunjukkan bahwa nilai tertinggi tingkat kesukaan panelis terhadap nilai kesukaan rasa sumping labu diperoleh dari perlakuan P1 yaitu 5,93 (suka) serta tidak berbeda dengan perlakuan P2 sedangkan nilai kesukaaan terendah diperoleh dari perlakuan P6 yaitu 3,50 (agak tidak suka) serta tidak bebeda dengan perlakuan P5 . Perbandingan tepung beras dengan labu kuning berpengaruh sangat nyata $(\mathrm{P}<0,01)$ terhadap skor rasa sumping labu. Tabel 5 menunjukkan bahwa nilai ratarata penerimaan terhadap rasa uji skoring sumping tertinggi diperoleh dari perlakuan P1 yaitu 4,53 (khas labu kuning) serta tidak berbeda dengan $\mathrm{P} 2$, sedangkan nilai terendah diperoleh dari perlakuan P6 yaitu 2,07 (tidak khas labu kuning) serta tidak berbeda dengan perlakuan P5.

Hal ini disebabkan karena banyak penambahan labu kuning sehingga rasa sumping labu yang dihasilkan rasa khas labu kuning kuat. Menurut Khasanah (2003) menyatakan bahwa rasa adalah faktor yang dinilai panelis setelah tekstur, warna dan aroma yang dapat yang mempengaruhi penerimaan produk pangan. Rasa yang enak dapat menarik perhatian sehingga konsumen lebih cenderung menyukai makanan dari rasanya.

\section{Penerimaan Keseluruhan}

Hasil analisis ragam menunjukkan bahwa perbandingan tepung beras dengan labu kuning berpengaruh sangat nyata $(\mathrm{P}<0,01)$ terhadap penerimaan keseluruhan sumping 
labu. Tabel 4 menunjukkan bahwa nilai ratarata tingkat kesukaan panelis terhadap penerimaan keseluruhan sumping labu berkisar antara 6,20 ( suka) sampai 3,53 (agak tidak suka). Nilai rata-rata tertinggi terhadap penerimaan keseeluruhan diperoleh pada perlakuan P1 yaitu 6,20 sedangkan nilai terendah diperoleh pada perlakuan P6 yaitu 3,53. Penilaian penerimaan keseluruhan panelis dipengaruh oleh beberapa faktor seperti warna, tekstur, aroma dan rasa pada sumping labu.

\section{KESIMPULAN DAN SARAN}

\section{Kesimpulan}

1. Perbandingan tepung beras dengan labu kuning berpengaruh terhadap kadar air, kadar abu, total karotenoid, evaluasi sensoris (uji hedonik dan uji skoring) sumping labu.

2. Perbandingan $25 \%$ tepung beras : $75 \%$ labu kuning mampu menghasilkan sumping labu dengan karakteristik terbaik dengan kadar air 57,55\%, kadar abu $1,74 \%$, total karotenoid $10868,52 \mu \mathrm{g} / \mathrm{g}$, warna kuning dan suka, aroma khas labu kuning dan agak suka, tekstur kenyal dan suka, rasa khas labu kuning dan suka serta penerimaan keseluruhan suka.

\section{Saran}

Berdasarkan hasil penelitian ini disarankan untuk :

1. Sumping labu dapat di olah dengan perbandingan $25 \%$ tepung beras : $75 \%$ labu dalam proses pembuatan sumping labu.

2. Perlu dilakukan penelitian lebih lanjut tentang umur simpan sumping labu dari hasil penambahan labu.

\section{DAFTAR PUSTAKA}

Anonimus. 2012. Sumping Waluh. http://kuenusantara.blogspot.com/20 12/09/ sumping-waluh.html. Diakses Pada Tanggal 2 Januari 2017.

Anonimus. 2016. Sumping Waluh. http://amynaraya.Wordpress.com/20 16/03/04/sumping-waluh.html. Diakses Pada Tanggal 4 Maret 2016.

Gomes, K. A. dan A. A. Gomes. 1995. Prosedur Statistik Untuk Penelitian Pertanian. UI Press. Jakarta.

Hendrasty, H.K. 2003. Tepung Labu Kuning: Pembuatandan Pemanfaatannya. Karnisius, Yogyakarta

Haryadi., 2006. Teknologi Pengolahan Beras.Gadjah Mada University Press, Yogyakarta.

Khasanah, U. 2003. Formulasi, Karakterisasi Fisiko-Kimia dan Organoleptik Produk Tortila Chip. Skripsi. Fakultas Teknologi Pertanian, IPB. Bogor

See, E. F., W. Nadiah., and A. Noor. 2007. Physico-Chemical and Organoleptic Evaluations of Wheat Bread Substituted with Different Percentage of Pumpkin Flour (Cucurbita moschata). ASEAN Food Journal, Vol. 14( 2) : 123-130.

Soekarto, S.T. 1985. Penilaian Organoleptik Untuk Industri Pangan dan Pertanian. Bharata Karya Aksara. Jakarta.

Sudarmadji, S., B. Haryono dan Suhardi. 1997. Analisa Bahan Makanan dan Pertanian. Liberty, Jakarta. 
Amalia, dkk.

Jurnal Ilmu dan Teknologi Pangan

Winarno, F. G. 2004. Kimia Pangan dan Gizi.

PT. Gramedia, Jakarta. 